\title{
FDI and Infrastructure Improvement of ASEAN
}

\author{
Xiaohui Wang ${ }^{1}$ \\ ${ }^{1}$ School of Economics and Management, LeShan Normal University, LeShan, Sichuan Province, China \\ Correspondence: Xiaohui Wang, School of Economics and Management, LeShan Normal University, No. 402, \\ Unit 2, JinLin, ManTingFang, No. 776, Xiaoba Road, LeShan City, Sichuan Province, China. E-mail: \\ scsnwxh@qq.com
}

Received: September 15, 2019

Accepted: September 28, 2019 Online Published: September 30, 2019

doi:10.5539/ijef.v11n10p140

URL: https://doi.org/10.5539/ijef.v11n10p140

\begin{abstract}
As a synthesis of capital, technology, knowledge and information, foreign direct investment(FDI) has a significant impact on the host country's economy, and the infrastructure is no exception which is an important part of one country's economy. This paper aims to empirically analyse the impact of FDI on infrastructure, using the panel data of ASEAN countries' infrastructure and FDI from 2003 to 2017 and compare the infrastructure effect of FDI from China and FDI from countries besides China. Result shows that FDI of ASEAN countries did improve the infrastructure level and for every 1\% increase in FDI of ASEAN countries, the infrastructure level of ASEAN countries rose $0.308 \%$. In addition, FDI from China of ASEAN countries did improve the infrastructure level and for every $1 \%$ increase in FDI from China of ASEAN countries, the infrastructure level of ASEAN countries rose $0.252 \%$. Therefore, as a bottleneck of ASEAN's economic development, infrastructure can be improved by attracting FDI, especially FDI from China.
\end{abstract}

Keywords: FDI, infrastructure, ASEAN, China, panel data

\section{Introduction}

Infrastructure, including transport, power, telecommunications, water supply and sanitation, is a fundamental input into production and productivity increasing. Aschauer (1989) verified the importance of infrastructure investment in stimulating economic growth through his research's result that the slowdown of economic growth in the United States around the 1980s was mainly due to the insufficient expansion of infrastructure investment. Esfahani and Ramirez(2003) pointed out that if African countries reached the level of East Asia in investment in telecommunications and energy infrastructure construction in the 1980s and 1990s, their annual economic growth rate would be 1.3 percentage points higher. Similar conclusions have been drawn in empirical studies on China by Démurger (2001), Qingwang and Junxue (2006). Furthermore, many empirical studies believed that good infrastructure can promote economic growth through the improvement of production efficiency (Hulten et al., 2006; Agénor et al., 2006), transaction efficiency (Holl, 2004; Michaels, 2008) and spillover effect (Cohen \& Paul, 2004; Hulten et al., 2006; Zhang, 2012). But, an important problem faced by developing countries in economic development is the fact that imperfect infrastructure leads to high transaction costs (Yifu, 2016). The report of Meeting Asia's infrastructure needs by Asian Development Bank shows that developing countries in the Asia-Pacific region need to invest 6\% of GDP in infrastructure to sustain economic growth, but at present this proportion is less than 5\%. As important parts of Asia-Pacific countries, ASEAN's ten member countries have maintained relatively fast economic growth in the past period, but they also face the problem of imperfect infrastructure. In order to maintain a fast economic growth rate, the gap in infrastructure investment needs to be filled urgently.

Because of the shortage of capital and technology in ASEAN countries, it is difficult to fill the infrastructure gap by their own strength, so these countries must seek external sources of capital and technology. Since the 1960s, foreign direct investment(FDI) has always been a hot topic in the field of international economic research because of its important influence on economy of host country. As a combination of capital, technology and knowledge, FDI can directly and indirectly improve the infrastructure of the host country. In 2018, the FDI flow absorbed by ASEAN had came to 154712.98 million US\$, and 10187.47 from China with a proportion of 6.6\%. Have these FDI improved the infrastructure level of ASEAN countries? What is the mechanism through which FDI improve the host country's infrastructure? The answers to these questions will help ASEAN and all developing countries to make better use of FDI. Therefore, this paper empirically analyses the impact of FDI 
absorbed by ASEAN countries on their infrastructure level on the basis of analyzing the ways of FDI improving the infrastructure of host countries, and compares the differences of the impact of FDI between China and other countries on the infrastructure level of ASEAN countries.

\section{Literature Review}

With the rapid expansion of FDI worldwide since the 1960s, the theory of foreign direct investment has undergone a development from micro level to macro level. Since FDI originated in developed countries and was dominated by developed countries, the early FDI theory focused on the competitive advantage of investors, believing that multinational corporations in developed countries undertake foreign investment because of monopoly advantage (Hymer, 1960), internalization advantage (Buckley \& Casson, 1985), location advantage (Dunning, 1993) and marginal industrial expansion (Kojima, 1978). Some developing countries have achieved rapid economic growth through the use of FDI, which has attracted a lot of scholars' attention. A large number of studies have been made on the factors affecting the location selection of FDI and the impact of FDI on the economic growth of host countries. Part of these researches explore the relationship between FDI and infrastructure.

There are three main types of research on the relationship between FDI and infrastructure. One type of research focuses on the interaction effect of FDI and Infrastructure on economic growth. Nourzad et al. (2014) put forward hypotheses that the effect of FDI on per capita real income depends on the size of the host country's infrastructure and verified the hypothesis. Sui et al. (2017) analyzed the relationship between China's FDI in the countries along the Belt and Road, the infrastructure construction along the Belt and Road and the actual GDP of these countries based on the unbalanced panel data of 64 countries from 2003 to 2012. They found that about 30\% of the effect of China's foreign direct investment on economic growth of countries along the Belt and Road was achieved by improving the infrastructure level of these countries. Jiang et al. (2018) concluded that there is a institution threshold for the effect of China's OFDI on host country's economic growth through improve host country's infrastructure.

The second type of research focuses on the effect of infrastructure on FDI. These research believed that good infrastructure is an important factor to attract FDI. Globerman and Shapiro (2002) employed a broad sample of the developed and developing countries from 1995 to 1997 in their study and came to the conclusion that governance infrastructure is an important determinant of both FDI inflows and outflows. Ang (2008) used Malaysia's annual data from 1960 to 2005 in their research and found that the expansion of infrastructure, measured by government transport and communications expenditure, increased FDI inflows to host countries. Chakrabarti et al. (2017) employed unique data at the district level in India in their research and found that FDI inflows increased steeply with an increase in infrastructure.

The third type of research focuses on the effect of FDI on infrastructure. This type of research is relatively few, and the conclusions are inconsistent. Through their research, Yamin and Sinkovics (2009) believed that in the least developed countries, because of the low impact of FDI on development and the rising cost of attracting investment, FDI aggravated the constraints of Government Finance on infrastructure construction and had a negative impact on infrastructure development. Huang et al. (2018) used the unbalanced panel data of 64 countries along the Belt and Road from 2003 to 2013 to analyze the impact of China's direct investment to the countries along the Belt and Road on infrastructure. They found that China's direct investment in the countries along the Belt and Road significantly improved the infrastructure level of these countries.

From the existing research, FDI has a great impact on the infrastructure of the host country, but few studies focus on the impact of FDI on infrastructure, and the conclusions are inconsistent. Thus, this paper aims to empirically analyse the impact of FDI absorbed by ASEAN countries on their infrastructure level on the basis of analyzing the ways of FDI improving the infrastructure of host countries, and compares the differences of the impact of FDI between China and other countries on the infrastructure level of ASEAN countries.

\section{Research Design}

\subsection{Theoretical Analysis}

For the host country, FDI means not only capital inflow, but also the inflow of advanced technology, knowledge and management experience. It can also bring up-to-date market information and increase export opportunities. Because of the above advantages, FDI can improve the infrastructure level of the host country directly and indirectly, and further promote the economic development of the host country.

Firstly, part of FDI invest directly in the infrastructure industry of the host country, which can directly improve the infrastructure level of the host country. Taking China's FDI in ASEAN as an example, the amount and 
proportion of China's investment in the main ASEAN infrastructure industries in 2017 are as follows: 1896 million US dollars in Construction industry, accounting for 13.4\%; 758 million US dollars in Transportation, Storage and Postal Services industry, accounting for 5.4\%; 633 million US dollars in Production and Supply of Electricity, Heat, Gas and Water industry, accounting for 4.5\%; 168 million US dollars in Public Health and Social Work industry, accounting for 1.2\%; 47 million US dollars in Water Conservancy, Environment and Public Facility Management industry, accounting for $0.3 \%$. These investments have greatly improved the infrastructure level of ASEAN countries and laid an important foundation for their long-term economic development.

Secondly, the advanced technology, knowledge and management experience brought by FDI can improve the infrastructure level of the host country by improving the technology level and efficiency of the host country. After the upgrading of the host country's technology level, the infrastructure construction that could not be implemented before due to technical bottlenecks can be put on the agenda, thus improving the implementation level of the host country's infrastructure. In addition, due to the improvement of investment efficiency, the same amount of investment can achieve more infrastructure investment than before.

Thirdly, the market opportunities brought by FDI can form a competitive effect and increase domestic private and government investment in infrastructure in host countries. The region that successfully attracts FDI can achieve better economic development. In order to play the role of FDI in a better way, regional governments will make greater investment in infrastructure support. If other regions want to attract FDI, they must also improve local infrastructure. As a result, this competitive effect raises the level of infrastructure in host countries.

\subsection{Model Specification}

Infrastructure is not only the basic material condition of a country's economic activities, but also an important manifestation of a country's material living standard. Therefore, the level of infrastructure is affected by the level of economic development and economic structure. This paper holds that the speed of economic growth, economic structure and export of a country are all important internal factors affecting the level of infrastructure, while one of external factors affecting the level of infrastructure of a country is FDI, which is the focus of this study. Therefore, the basic research model of this paper is constructed as follows:

$$
\operatorname{lnINF_{it}}=\beta_{0}+\beta_{I} \ln F D I_{i t}+\beta_{2} G D P G_{i t}+\beta_{3} S T R U_{i t}+\beta_{4} \ln E X P_{i t}+\varepsilon_{i t}
$$

Where $I N F_{i t}$ represents infrastructure level of $i$ country in $t$ year, $F D I_{i t}$ represents FDI stock of $i$ country in $t$ year, $G D P G_{i t}$ represents GDP growth of $i$ country in $t$ year, $S T R U_{i t}$ represents the economic structure of $i$ country in $t$ year, $E X P_{i t}$ represents the amount of export of $i$ country in $t$ year, $\varepsilon_{i t}$ represents the random disturbance term. The dependent variables and key independent variables in the model are in logarithmic form, because logarithmic model can study the elastic relationship between dependent variables and independent variables, solve the problem of heteroscedasticity and make biased data close to normal distribution.

China's outward FDI has been at the forefront of the world in recent years. As a developing country, China's outward FDI is different from that of developed countries. The main differences include that China's outward FDI can bring the successful experience of China's development to developing host countries, and invests a lot in the field of infrastructure. Therefore, China's outward FDI is more in line with the needs of developing host countries' economic development. So, on the basis of basic model research, this paper further explores the difference between China's outward FDI and other countries' outward FDI in the impact of ASEAN infrastructure.

$$
\operatorname{lnINF}_{i t}=\theta_{0}+\theta_{1} \ln F D I C_{i t}+\theta_{2} \ln F D I O_{i t}+\theta_{3} G D P G_{i t}+\theta_{4} S T R U_{i t}+\theta_{5} \ln E X P_{i t}+\varepsilon_{i t}
$$

Where $F D I C_{i t}$ represents FDI stock from China of $i$ country in $t$ year, $F D I O_{i t}$ represents FDI stock from countries besides China of $i$ country in $t$ year. Coefficient $\theta_{1}$ and $\theta_{2}$ indicate the impact of China's and other countries' investment in ASEAN on ASEAN's infrastructure level, respectively.

\subsection{Data and Descriptive Statistics}

This paper aims to empirically analyse the impact of FDI absorbed by ASEAN countries on their infrastructure level. So the sample countries are ten ASEAN countries. Annual panel data span from 2003 to 2017 because that the data of China's investment in 10 ASEAN countries have been published since 2003.

Infrastructure involves a wide range of industries, such as transport, power, telecommunications, water supply and sanitation. In order to reflect a country's infrastructure level more comprehensively, this paper determines the weights of various industries through the entropy method, thus forming a comprehensive infrastructure index. Due to the lack of data, this paper selected the data of length of paved road from ASEAN official website, the 
data of electric power consumption (kWh per capita) from World Development Indicators(WDI), the data of fixed telephone subscriptions (per 100 people) from WDI, the data of mobile cellular subscriptions (per 100 people) from WDI and the data of individuals using the Internet (\% of population) from WDI as the component of infrastructure comprehensive indicators.

The data of inward FDI of ASEAN countries comes from United Nations Conference on Trade and Development(UNCTAD), the data of inward FDI from China of ASEAN countries comes from Statistical Bulletin of China's Outward Foreign Direct Investment. The data of GDP growth and export come from WDI. This paper uses the proportion of secondary and third industries as an indicator of economic structure, data of which comes from WDI. The descriptive statistics of all variables are as shown in table 1 . As can be seen from table 1, this paper applies balanced panel data, the standard deviation of all data is small and there is no extreme value. Therefore, the balanced panel data used in this paper do not need to be further processed and can be used for regression analysis.

Table 1. Variable descriptive statistics

\begin{tabular}{|c|c|c|c|c|c|c|}
\hline variable & & Mean & Std.Dev. & Min & Max & Observations \\
\hline \multirow{3}{*}{$\operatorname{loginf}$} & overall & -.9569755 & .6108911 & -2.094267 & -.0395055 & $\mathrm{~N}=150$ \\
\hline & between & & .5323357 & -1.765939 & -.1314958 & $\mathrm{n}=10$ \\
\hline & within & & .3412229 & -1.83324 & -.0997423 & $\mathrm{~T}=15$ \\
\hline \multirow{3}{*}{$\operatorname{logfdi}$} & overall & 10.28782 & 1.807148 & 6.455431 & 14.06621 & $\mathrm{~N}=150$ \\
\hline & between & & 1.76589 & 7.627364 & 13.22775 & $\mathrm{n}=10$ \\
\hline & within & & .6636407 & 8.017071 & 11.67233 & $\mathrm{~T}=15$ \\
\hline \multirow{3}{*}{ logfdic } & overall & 6.21704 & 2.288942 & -2.040221 & 10.70477 & $\mathrm{~N}=150$ \\
\hline & between & & 1.49777 & 2.609852 & 8.319939 & $\mathrm{n}=10$ \\
\hline & within & & 1.790732 & 1.566967 & 9.003857 & $\mathrm{~T}=15$ \\
\hline \multirow{3}{*}{ logfdio } & overall & 10.16702 & 1.93158 & 6.441007 & 14.03091 & $\mathrm{~N}=150$ \\
\hline & between & & 1.932723 & 6.80688 & 13.21456 & $\mathrm{n}=10$ \\
\hline & within & & .5886933 & 7.906992 & 11.23579 & $\mathrm{~T}=15$ \\
\hline \multirow{3}{*}{ gdpg } & overall & 5.755182 & 3.22147 & -2.465515 & 14.52565 & $\mathrm{~N}=150$ \\
\hline & between & & 2.48438 & .3814403 & 9.695994 & $\mathrm{n}=10$ \\
\hline & within & & 2.187615 & -1.877171 & 14.59827 & $\mathrm{~T}=15$ \\
\hline \multirow{3}{*}{ stru } & overall & 84.61145 & 11.74646 & 49.37944 & 99.97389 & $\mathrm{~N}=150$ \\
\hline & between & & 11.80046 & 63.73494 & 99.95943 & $\mathrm{n}=10$ \\
\hline & within & & 3.43694 & 70.25595 & 97.54177 & $\mathrm{~T}=15$ \\
\hline \multirow{3}{*}{ logexp } & overall & 10.30394 & 2.461176 & 2.982299 & 13.31194 & $\mathrm{~N}=150$ \\
\hline & between & & 2.352735 & 5.779264 & 12.96457 & $\mathrm{n}=10$ \\
\hline & within & & 1.020847 & 7.506976 & 14.02171 & $\mathrm{~T}=15$ \\
\hline
\end{tabular}

This paper draws scatter plots of ASEAN's infrastructure and FDI, ASEAN's infrastructure and FDI from China and ASEAN's infrastructure and FDI from countries besides China separately to find out their relationship preliminarily. According to figure 1, figure 2 and figure 3, we can find out that there are positive relationship between ASEAN's infrastructure and FDI, ASEAN's infrastructure and FDI from China and ASEAN's infrastructure and FDI from countries besides China. But, these positive relationships need empirical proof.

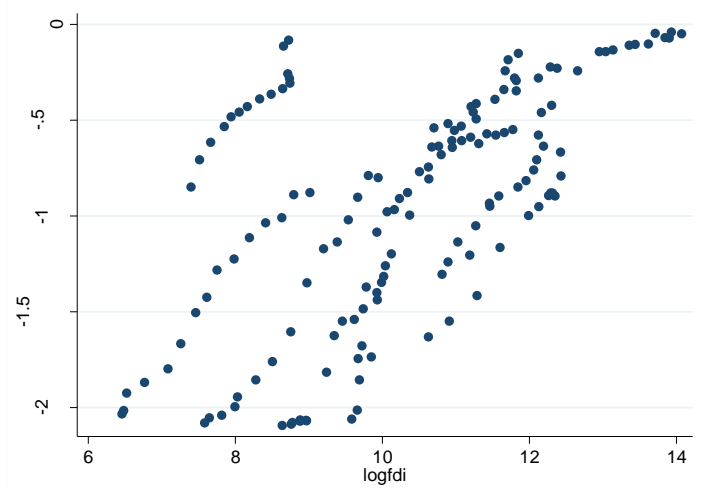

Figure 1. Scatter plot of FDI and Infrastructure of ASEAN 


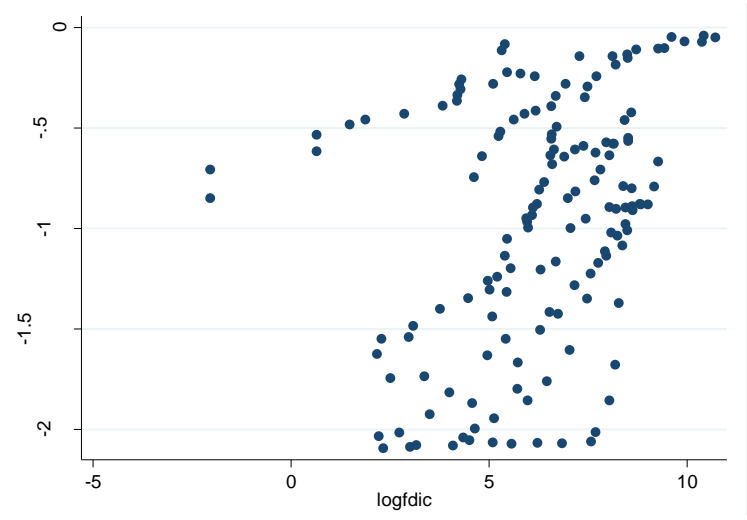

Figure 2. Scatter plot of FDI from China and Infrastructure of ASEAN

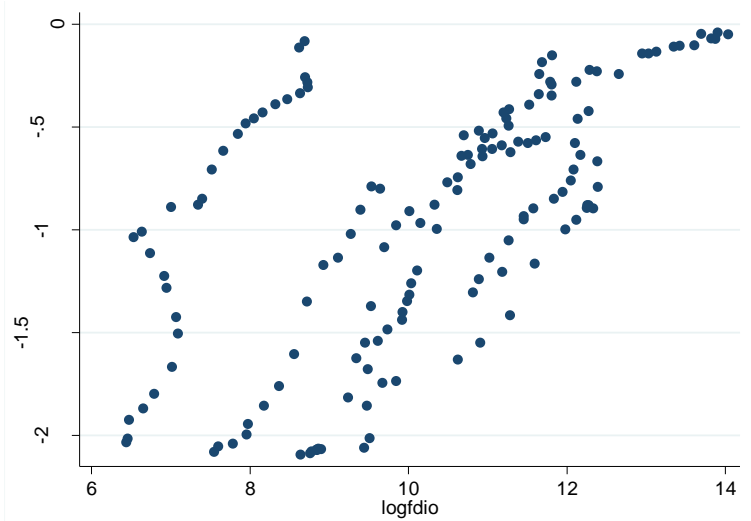

Figure 3. Scatter plot of FDI from Countries besides China and Infrastructure of ASEAN

\section{Empirical Analysis}

\subsection{Research Method}

This paper employs Stata to make regression of panel data of the infrastructure level and FDI of ten ASEAN countries from 2003 to 2017. At first, stationary test is made to avoid false regression. Then, pool regression, random effect and fixed effect regression are made in turn to estimate model (1) to find out whether FDI has a positive effect on infrastructure. Next, hausman test is made to find out the most suitable method. Because the method of GMM allow heteroscedasticity and serial correlation in the random error, this paper employ GMM to estimate model (1) and model (2) to find out whether there is difference between the infrastructure effect of FDI from China and FDI from countries besides China.

\subsection{Stationary Test}

The stationary tests are made by the method of LLC, Harris-Tzavalis, Breitung, ips, dfuller and pperron, and the results are shown in table 2 and table 3 . According to table 2 and table 3, we found that all variables are not stationary, but the difference of all variables are stationary.

Table 2. Results of stationary test of all variables

\begin{tabular}{cllllllll}
\hline variable & & loginf & logfdi & gdpg & stru & logexp & logfdic & logfdio \\
\hline \multirow{2}{*}{ LLC } & statistic & -2.1117 & -3.0104 & -3.6941 & -1.9640 & -4.7309 & -5.3443 & -3.3227 \\
& P value & 0.0174 & 0.0013 & 0.0001 & 0.0248 & 0.0000 & 0.0000 & 0.0004 \\
& statistic & 0.9700 & 0.9338 & 0.2157 & 0.9540 & 0.9247 & 0.8944 & 0.9081 \\
\multirow{2}{*}{ HT } & P value & 0.9952 & 0.9768 & 0.0000 & 0.9899 & 0.9674 & 0.9107 & 0.9418 \\
& statistic & 6.3427 & 6.8573 & -2.8008 & 3.4782 & 3.8552 & 5.7196 & 6.1358 \\
\hline \multirow{2}{*}{ Breitung } & P value & 1.0000 & 1.0000 & 0.0025 & 0.9997 & 0.9999 & 1.0000 & 1.0000 \\
\hline
\end{tabular}




\begin{tabular}{cllllllll}
\hline \multirow{2}{*}{ ips } & statistic & 1.6854 & 1.8978 & -3.6542 & 0.7524 & -1.6989 & -0.3064 & 1.0792 \\
& P value & 0.9540 & 0.9711 & 0.0001 & 0.7741 & 0.0447 & 0.3796 & 0.8597 \\
\multirow{2}{*}{ dfuller } & statistic & 3.6136 & 0.8156 & 9.0149 & -0.5354 & 1.8507 & 1.5115 & 0.9709 \\
& P value & 0.0002 & 0.2074 & 0.0000 & 0.7038 & 0.0321 & 0.0653 & 0.1658 \\
\multirow{2}{*}{ pperron } & statistic & 3.6136 & 0.8156 & 9.0149 & -0.5354 & 1.8507 & 1.5115 & 0.9709 \\
& P value & 0.0002 & 0.2074 & 0.0000 & 0.7038 & 0.0321 & 0.0653 & 0.1658 \\
\hline
\end{tabular}

Table 3. Results of stationary test of difference of all variables

\begin{tabular}{cllllllll}
\hline variable & & Dloginf & Dlogfdi & Dgdpg & Dstru & Dlogexp & Dlogfdic & Dlogfdio \\
\hline \multirow{2}{*}{ LLC } & statistic & -2.5269 & -6.7049 & -8.3917 & -4.9188 & -4.5778 & -2.0783 & -4.6672 \\
& P value & 0.0058 & 0.0000 & 0.0000 & 0.0000 & 0.0000 & 0.0188 & 0.0000 \\
& statistic & 0.4154 & 0.1981 & -0.4036 & 0.1583 & 0.0074 & -0.1826 & 0.2705 \\
HT & P value & 0.0000 & 0.0000 & 0.0000 & 0.0000 & 0.0000 & 0.0000 & 0.0000 \\
& statistic & -2.7062 & -4.0904 & -7.1768 & -5.1224 & -5.7768 & -3.3701 & -4.6749 \\
Breitung & P value & 0.0034 & 0.0000 & 0.0000 & 0.0000 & 0.0000 & 0.0004 & 0.0000 \\
& statistic & -3.8937 & -3.5156 & -6.1569 & -4.1052 & -4.8621 & -5.1275 & -3.1001 \\
ips & P value & 0.0000 & 0.0002 & 0.0000 & 0.0000 & 0.0000 & 0.0000 & 0.0010 \\
& statistic & 10.1653 & 6.2584 & 30.2016 & 9.2309 & 11.7026 & 29.9061 & 6.1261 \\
& P value & 0.0000 & 0.0000 & 0.0000 & 0.0000 & 0.0000 & 0.0000 & 0.0000 \\
& statistic & 10.1653 & 6.2584 & 30.2016 & 9.2309 & 11.7026 & 29.9061 & 6.1261 \\
& P value & 0.0000 & 0.0000 & 0.0000 & 0.0000 & 0.0000 & 0.0000 & 0.0000 \\
\hline
\end{tabular}

Co-integration test is made to find out if there are co-integration relationships between dependent variable and independent variables both in model (1) and model (2), because all variables are integrated of order one I(1) rather than integrated of order zero I(0). The results of test are shown in table 4 and table 5 . According to table 4 and table 5, there are co-integration relationships between dependent variable and independent variables both in model (1) and model (2). Therefore, false regression can be avoided both in model (1) and model (2).

Table 4. Result of co-integration test of model (1)

\begin{tabular}{ccccc}
\hline Statistic & Value & Z-value & P-value & Robust P-value \\
\hline $\mathrm{Gt}$ & -1.8 & 0.55 & 0.709 & 0 \\
$\mathrm{Ga}$ & -2.674 & 3.204 & 0.999 & 0 \\
$\mathrm{Pt}$ & -3.763 & 1.065 & 0.857 & 0 \\
$\mathrm{~Pa}$ & -1.279 & 2.092 & 0.982 & 1 \\
\hline
\end{tabular}

Table 5. Result of co-integration test of model (2)

\begin{tabular}{ccccc}
\hline Statistic & Value & Z-value & P-value & Robust P-value \\
\hline $\mathrm{Gt}$ & -3.396 & -3.722 & 0 & 0 \\
$\mathrm{Ga}$ & -2.266 & 3.895 & 1 & 0 \\
$\mathrm{Pt}$ & -2.82 & 2.561 & 0.995 & 0 \\
$\mathrm{~Pa}$ & -1.185 & 2.723 & 0.997 & 0 \\
\hline
\end{tabular}

\subsection{Regression Analysis}

The results of regression 1 to 6 for model (1) and regression 7 for model (2) are shown as in table 6 . According to table 6 , most coefficients are significant except regression 6 , the r-squared of regression is between 0.755 to 0.855 , which indicate that the results of regression 1 to 5 and regression 7 are perfect. The result of hausman test shows that fixed effect is more suitable. In addition, according to results of regression 3 to 5 , regression 5 which fixes the year effect is the most perfect regression because significant coefficients in regression 5 are more than those of regression 3 and 4, and the r-square is the largest. Therefore, this paper focus on the analysis of results of regression 5 and regression 7 which applies the method of GMM. 
Table 6. Regression result

\begin{tabular}{|c|c|c|c|c|c|c|c|}
\hline explaining & Regress 1 & Regress 2 & Regress 3 & Regress 4 & Regress 5 & Regress 6 & Regress 7 \\
\hline variables & POOL & $\mathrm{RE}$ & FE & FE+Robust & $\mathrm{FE}+$ Year & GMM & GMM \\
\hline $\operatorname{logfdi}$ & $\begin{array}{c}0.130 * * * \\
(0.0327)\end{array}$ & $\begin{array}{c}0.363 * * * \\
(0.0234)\end{array}$ & $\begin{array}{c}0.402 * * * \\
(0.0216)\end{array}$ & $\begin{array}{c}0.402 * * * \\
(0.0575)\end{array}$ & $\begin{array}{c}0.308 * * * \\
(0.0562)\end{array}$ & $\begin{array}{c}0.155 \\
(0.257)\end{array}$ & \\
\hline logfdic & & & & & & & $\begin{array}{c}0.252 * * * \\
(0.0799)\end{array}$ \\
\hline logfdio & & & & & & & $\begin{array}{l}-0.349^{*} \\
(0.181)\end{array}$ \\
\hline gdpg & $\begin{array}{l}-0.0162 \\
(0.0124)\end{array}$ & $\begin{array}{c}0.00135 \\
(0.00635)\end{array}$ & $\begin{array}{c}0.00631 \\
(0.00570)\end{array}$ & $\begin{array}{c}0.00631 \\
(0.00694)\end{array}$ & $\begin{array}{l}0.0156^{* *} \\
(0.00714)\end{array}$ & $\begin{array}{l}-0.0196 \\
(0.0151)\end{array}$ & $\begin{array}{l}0.00263 \\
(0.0117)\end{array}$ \\
\hline stru & $\begin{array}{c}0.0362 \text { *** } \\
(0.00750)\end{array}$ & $\begin{array}{c}0.0179 * * * \\
(0.00588)\end{array}$ & $\begin{array}{c}0.00951 \\
(0.00604)\end{array}$ & $\begin{array}{c}0.00951 \\
(0.00886)\end{array}$ & $\begin{array}{c}0.00567 \\
(0.00648)\end{array}$ & $\begin{array}{c}0.0292 \\
(0.0742)\end{array}$ & $\begin{array}{c}0.0541 * * \\
(0.0244)\end{array}$ \\
\hline logexp & $\begin{array}{l}-0.0368 \\
(0.0473)\end{array}$ & $\begin{array}{c}0.0195 \\
(0.0226)\end{array}$ & $\begin{array}{c}0.0464 * * \\
(0.0216)\end{array}$ & $\begin{array}{l}0.0464 * \\
(0.0242)\end{array}$ & $\begin{array}{c}0.0585 * * \\
(0.0233)\end{array}$ & $\begin{array}{c}-0.0290 \\
(0.0913)\end{array}$ & $\begin{array}{r}-0.00853 \\
(0.0359)\end{array}$ \\
\hline Constant & $\begin{array}{c}-4.882 * * * \\
(0.439)\end{array}$ & $\begin{array}{c}-6.415^{* * *} \\
(0.395)\end{array}$ & $\begin{array}{c}-6.410 * * * \\
(0.382)\end{array}$ & $\begin{array}{c}-6.410^{* * *} \\
(0.517)\end{array}$ & $\begin{array}{c}-5.395 * * * \\
(0.611)\end{array}$ & $\begin{array}{l}-4.588 \\
(3.745)\end{array}$ & $\begin{array}{c}-3.502 * * \\
(1.454)\end{array}$ \\
\hline Observations & 150 & 150 & 150 & 150 & 150 & 150 & 150 \\
\hline $\mathrm{R}$-squared & 0.755 & 0.8356 & 0.840 & 0.840 & 0.855 & & \\
\hline Number of Country & & 10 & 10 & 10 & 10 & 10 & 10 \\
\hline
\end{tabular}

Robust standard errors in parentheses; $* * * \mathrm{p}<0.01, * * \mathrm{p}<0.05, * \mathrm{p}<0.1$.

The coefficients of logfdi in regression 1 to regression 5 are all positive and significant, which verifies empirically that FDI of ASEAN countries did improve the infrastructure level of ASEAN countries. According to the result of regression 5, the coefficient of logfdi is 0.308 , which means that for every $1 \%$ increase in FDI of ASEAN countries, the infrastructure level of ASEAN countries rose $0.308 \%$. In regression 7 which applies the method of GMM, the coefficients of logfdic and logfdio are all significant and come to 0.252 and -0.349 separately, which indicate that FDI from China of ASEAN countries did improve the infrastructure level of ASEAN countries and FDI from countries besides China of ASEAN countries did not improve the infrastructure level of ASEAN countries. Because the amount of coefficient of logfdic in regression 7 comes to 0.252 , we can also come to the conclusion that for every $1 \%$ increase in FDI from China of ASEAN countries, the infrastructure level of ASEAN countries rose $0.252 \%$.

\section{Conclusion and Suggestion}

\subsection{Research Conclusion}

This paper aims to empirically analyse the impact of FDI on infrastructure on the basis of analyzing the mechanism of FDI improving the infrastructure of host countries using the panel data of ASEAN countries' infrastructure and FDI from 2003 to 2017. Furthermore, this paper makes a comparison between the infrastructure effect of FDI from China and FDI from countries besides China. Through research, this paper finds that FDI of ASEAN countries did improve the infrastructure level and for every $1 \%$ increase in FDI of ASEAN countries, the infrastructure level of ASEAN countries rose by $0.308 \%$. In addition, FDI from China of ASEAN countries did improve the infrastructure level and for every $1 \%$ increase in FDI from China of ASEAN countries, the infrastructure level of ASEAN countries rose by $0.252 \%$, but FDI from countries besides China of ASEAN countries did not improve the infrastructure level of ASEAN countries. Therefore, this paper comes to the conclusion that FDI from China of ASEAN countries has a positive effect on infrastructure, while FDI from countries besides China does not have a positive effect on infrastructure. Finding the difference is an important contribution of this paper. But, this paper don't analyse the reason of the difference empirically. It is the limitation of this research and also a new research direction.

\subsection{Suggestion}

Because China's economic development background is the same as that of most developing countries, accompanied by China's successful development experience, China's outward foreign direct investment has a tremendous impact on promoting the infrastructure and economic development of developing countries. So, ASEAN countries and other developing countries should strengthen economic cooperation with China, promote mutual investment and achieve common prosperity. 


\section{References}

Agenor, P. R., \& Moreno-Dodson, B. (2006). Public infrastructure and growth: New channels and policy implications. Policy Research Working Paper Series, (59), 1-59. https://doi.org/10.2139/ssrn.2005043

Ang, J. B. (2008). Determinants of foreign direct investment in malaysia. Journal of Policy Modeling, 30(1), 185-189. https://doi.org/10.1016/j.jpolmod.2007.06.014

Aschauer, D. A. (1989). Is public expenditure productive? Staff Memoranda, 23(2), 177-200. https://doi.org/10.1016/0304-3932(89)90047-0

Chakrabarti, R., Subramanian, K., \& Meka, S. (2017). Localization of fdi flows: Evidence on infrastructure as a critical determinant. Social Science Electronic Publishing, 2(1), 205-246. https://doi.org/10.1561/108.00000016

Cohen, J. P., \& Paul, C. J. M. (2004). Public infrastructure investment, interstate spatial spillovers, and manufacturing costs. Review of Economics and Statistics, 86(2), 551-560. https://doi.org/10.1162/003465304323031102

Démurger, S. (2001). Infrastructure development and economic growth: An explanation for regional disparities in China? Journal of Comparative Economics, 29(1), 0-117. https://doi.org/10.1006/jcec.2000.1693

Esfahani, H. S., \& María Teresa Ramírez. (2003). Institutions, infrastructure, and economic growth. Journal of Development Economics, 70(2), 443-477. https://doi.org/10.1016/S0304-3878(02)00105-0

Globerman, S., \& Shapiro, D. (2002). Global Foreign Direct Investment Flows: The Role of Governance Infrastructure. World Development, 30(11), 1899-1920. https://doi.org/10.1016/S0305-750X(02)00110-9

Guo, Q. W., \& Jia, J. X. (2006). The Effects of Government Public Capital Investment on Long-Run Economic Growth. Economic Research Journal, 41(7), 29-40.

Holl, A. (2004). Manufacturing location and impacts of road transport infrastructure: Empirical evidence from Spain. Regional Science \& Urban Economics, 34(3), 341-363. https://doi.org/10.1016/S0166-0462(03)00059-0

Huang, L. X., Qian, X. B., \& Sui, G. J. (2018). Have China's FDIs Improved the Infrastructure of Countries along the Belt and Road?. Management Review, 30(3), 226-239.

Hulten, C. R., Bennathan, E., \& Srinivasan, S. (2006). Infrastructure, externalities, and economic development: a study of the indian manufacturing industry. The World Bank Economic Review, 20(2), 291-308. https://doi.org/10.1093/wber/lhj007

Jiang, H., \& Sun, Y. Q. (2018). China's OFDI, host country infrastructure construction and bilateral economic growth-From the Perspective of "The Belt and Road" Host Country System. Economic Theory and Business Management, 336(12), 86-99.

Michaels, G. (2008). The effect of trade on the demand for skill: Evidence from the interstate highway system. Review of Economics and Statistics, 90(4), 683-701. https://doi.org/10.2139/ssrn.903393

Nourzad, F., Greenwold, D. N., \& Yang, R. (2014). The interaction between FDI and infrastructure capital in the development process. International Advances in Economic Research, 20(2), 203-212. https://doi.org/10.1007/s11294-013-9457-5

Sui, G. J., Huang, L. X., \& Huang, X. (2017). China's Foreign Direct Investment, Infrastructure Construction and the "Belt and Road" National Economic Growth. Journal of Guangdong University of Finance \& Economics, 32(1), 32-43.

Wang, X. H. (2018). Industrial Upgrading Effect of OFDI of Sichuan Province of China. International Journal of Economics and Finance, 10(10), 138-144. https://doi.org/10.5539/ijef.v10n10p138

Yamin, M., \& Sinkovics, R. (2009). Infrastructure or foreign direct investment? An examination of the implications of MNE strategy for economic development. Journal of World Business, 44, 144-157. https://doi.org/10.1016/j.jwb.2008.05.004

\section{Copyrights}

Copyright for this article is retained by the author(s), with first publication rights granted to the journal.

This is an open-access article distributed under the terms and conditions of the Creative Commons Attribution license (http://creativecommons.org/licenses/by/4.0/). 